Çukurova Üniversitesi Mühendislik Fakültesi Dergisi, 36(1), ss. 89-103, Mart 2021

Cukurova University Journal of the Faculty of Engineering, 36(1), pp. 89-103, March 2021

\title{
Akıllı Tekstil Ürünü Olarak Spor Ceket: Yeni Bir Ürüne Yönelik Tüketici Tepkilerinin Örneklem Özelliklerine Göre Değişimi
}

\author{
Gülden TURHAN*1, Füsun DOBA KADEM² \\ ${ }^{1}$ Marmara Üniversitesi, Teknoloji Fakültesi, Tekstil Mühendisliği Bölümü, İstanbul \\ ${ }^{2}$ Çukurova Üniversitesi, Mühendislik Fakültesi, Tekstil Mühendisliği Bölümü, Adana
}

Geliş tarihi: 12.01 .2021

Kabul tarihi: 31.03 .2021

\section{Özet}

Farklı kişilerin yeni bir ürüne yönelik davranışsal, duygusal ve bilişsel olarak vereceği tepkiler aynı olmayabilir. Bu çalışmada yeni bir ürün örneği olarak akıllı tekstil ürünlerinden şekil hafızalı spor ceket ürünü incelenmiştir. Akıllı ceket ürünü için satın alma niyeti, ürüne karşı hisleri ve düşüncelerinin kişilerin sahip olduğu demografik ve/veya ekonomik özelliklere göre farklılaşıp farklılaşmadığını anlamak için 609 kişiden toplanan veriler analiz edilmiştir. Tüketicileri karakterize eden bir dizi demografik özellikler içerisinden cinsiyet, doğum yeri, yaş, medeni hal ve eğitim düzeyi gibi birtakım belirleyici değişkenler seçilmiştir. Ailenin aylık gelir seviyesi, aynı evi paylaştığı kişiler, araba ve ev sahipliği, çalışma durumu gibi ekonomik durumu açıklayan farklı göstergelere de yer verilmiştir. Araştırma sonuçları sadece eğitim düzeyi demografik değişkeni açısından tüketicilerin akıllı cekete karşı olan tepkilerinde anlamlı bir farklılık olduğunu ortaya koymuştur.

Anahtar Kelimeler: Akıllı ceket, Satın alma niyeti, Duygusal tepkiler, Bilişsel tepkiler, Eğitim düzeyi

\section{Sports Jacket as a Smart Textile Product: Change of Consumer Reactions to a New Product According to Sample Characteristics}

\begin{abstract}
Behavioral, emotional and cognitive responses of different people to a new product may not be the same. In this study, as a new product example, a shape memory sports jacket product, which is one of smart textile products, is examined. Data collected from 609 people were analyzed in order to understand whether the purchase intention, feelings and thoughts of the smart jacket product differ according to the demographic and/or economic characteristics of the people. A number of determinant variables such as gender, place of birth, age, marital status, and education level were selected from a range of demographic characteristics that characterize consumers. Different indicators explaining the economic situation such as monthly income level of the family, people sharing the same house, car and house ownership, and working status are also included. The results of the research revealed that there is a significant difference only in terms of the education level demographic variable in the reactions of the consumers to the smart jacket.
\end{abstract}

Keywords: Smart jacket, Purchase intention, Emotional reactions, Cognitive responses, Education level

*Sorumlu yazar (Corresponding author): Gülden TURHAN, gturhan@marmara.edu.tr 


\section{GİRIŞ}

Günümüzde yenilik (inovasyon) kavramının hayatımıza girmesiyle, birçok sanayi kuruluşu ürün gamına yenilikçi ürünler ekleyebilmek için adeta birbiri ile yarışır hale gelmişlerdir. Ürün, süreç, pazarlama veya diğer alanlarda yenilik, katma değeri yüksek ürünlerin tasarlanmasını, ulusal ve uluslararası rekabetin ivmelenmesini sağlamıştır. Tekstil sektörünün Endüstri 4 ile dijital dönüşümü ile yenilik kavramı daha hızlı uygulanabilir bir hal almış, daha hızlı üretim ve kısa sürede teslimat ile işletmelerin verimlilik artışı hızla yükseliş göstermiştir. Özellikle hazır giyim tasarım uygulamalarında fonksiyonel özellikli elyaf, iplik veya kumaşlar ile katma değeri yüksek giyilebilir konfeksiyon ürünleri sektörün hılı ilerlemesine çok önemli katkı sağlamıştır.

TÜSİAD tarafından Türkiye üzerine yapılan bir araştırmada, dijital dönüşümde Tekstil sektörü pilot sektörlerden birisi olarak seçilmiştir. Endüstri 4.0 sürecine uyum sağlanması durumunda; verimlilikteki artışın \%4-7 arasında olacağ sanayide büyümenin $\% 3$ olacağı ve istihdamda ilk on yıl içinde $\% 5$ artış olacağı tespit edilmiştir. Dünya Ekonomik Forumu'nda 2025'te dünya nüfusunun \%10'unun internete bağlanabilen giyilebilir teknolojileri kullanacağı belirtilmiştir [1]. Bu tür tekstil ürünleri 'akıllı tekstil' olarak tanımlanmakta, dokuma, örme, dokusuz yüzey ile birlikte farklı yöntemler uygulanarak akıllı olmayı tetikleyen bir takım parametrelerle (sıcaklık, nem, 1şık, elektrik, radyasyon, pH, kimyasallar, 1sı, ses, manyetik alan gibi) çevre/kullanıcı etkileşimi neticesi fonksiyonellik sağlanarak, tüketici beklentileri üst seviyede karşılanabilmektedir. Tasarlanan ürün gerçekten akıllı tekstil ise harici uyaranlara tepki vererek davranışını ona göre ayarlayacaktır [2].

Teknolojinin hızlı ilerlemesi, akıllı tekstil ürünlerine tüketicilerin ilgisinin artmasını sağlamış ve beraberinde bu ürünlerin üretiminde çeşitliliğ hızlandırmıştır, böylece firmalar bu alanda birbiri ile yarışır hale gelmişlerdir. Akıllı lif ve kumaşlar giyim dışında birçok alanda kullanılmaktadır.
Uyumak üzere olan sürücüleri uyandıran araba koltukları, kalp atışlarınızı dinleyen yatak çarşafları, oda sıcaklığına göre renk değiştiren dokumalar, ne kadar hızlı koştuğumuzu söyleyen ayakkabılar, koltukların koluna iliştirilen televizyon ve müzik seti kumandaları, kumaş piyanolar gibi ürünler giyim dışında kullanılan akıllı tekstillere örnek gösterilebilir [3].

Tekstil ürünlerinde fonksiyonellik ile birlikte estetik görünüm kazandırılarak elde edilen akıllı tekstil ürünleri şekil hafızalı materyaller kullanılarak da elde edilebilmektedir. Şekil hafızalı malzemeler, şeklini, geçici olarak deforme olmuş halinden, önceden programlanmış orijinal şekline, bir dış uyaranın etkisiyle kontrollü bir biçimde değiştirilebilen malzemelerdir. Şekil geri dönüşü, çevre sıcaklığı, elektrik akımı, 1sı, 1şık, manyetik alan, pH, UV 1ş1k, belirli bir kimyasal veya herhangi başka bir uyaran tarafından tetiklenebilir [4]. Şekil hafızalı malzemeler, bileşenlerine göre inorganik veya organik olabilmektedir. İnorganik şekil hafızalı malzemeler, metal alaşımlar, seramikler ve camlar, organik şekil hafızalı malzemeler ise polimerler ve jelleri kapsamaktadır.

Şekil hafızalı materyaller (shape memory materials), o an bulundukları şekilden daha önce belirlenmiş bir şekle, (genellikle 1sı sebebiyle) form değiştirerek geçerler. Bu tür malzemeler, aşırı sıcak veya soğuk ortam şartları karşısında yalıtım ve koruma özelliğinin artırılması amacıyla kullanılmaktadır. Bu özelliğe sahip konfeksiyon ürünleri aktive edildiğinde giysi katmanları içerisinde birbirine yakın olan tabakaların aralarındaki boşluklar artar. Böylece dış ortam ile vücut arasında sıcaklık kaybını önleme amacıyla bir bariyer tabaka oluşturulması amaçlanır. Hem faz değiştiren materyaller hem de şekil hafızalı materyaller kişinin fiziksel aktivitesi ve içinde bulunduğu ortam şartlarına (sıcaklık, nem, vb.) bağlı olarak tepki vermektedir [5]. Biçimsel hafızalı materyallerden elde edilen akıllı tekstil ürünü Şekil 1'de verilmiştir.

Hava şartlarına göre uyum sağlayabilen akıllı tekstiller, sıklıklarını, hava geçirgenliklerini, giysi formlarında kol, bacak vs. uzunluklarını değiştirebilmekte, giysiyi giyen bireyi mevsim 
şartlarına göre en uygun durumda hazırlayabilmektedirler. Örneğin bir gömlekte kullanılan şekil hafızalı alaşım sayesinde, vücut sıcaklığı arttığında, gömleğin kolları kendi üzerine sarılarak kısalmakta ve daha sonra saç kurutma makinasıyla 1sıtılınca orijinal şekline geri dönmektedir (Şekil 1) [4].

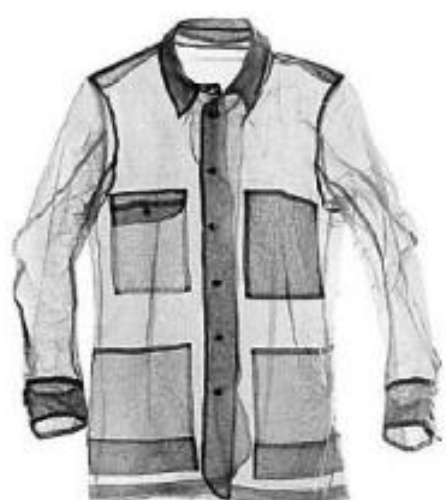

Şekil 1. Şekil hafızalı gömlek [4]

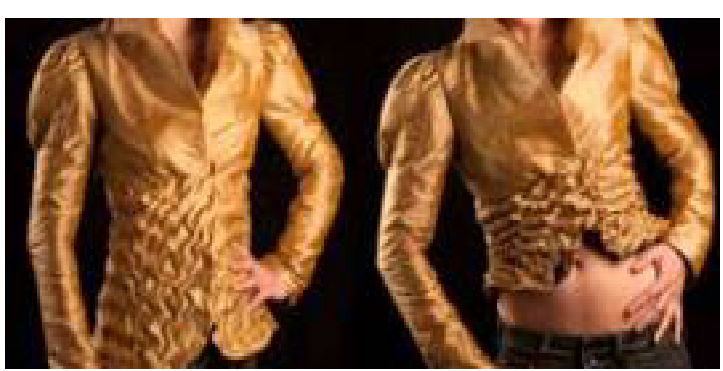

Şekil 2. Şekil hafızalı ceket [6]

Şekil 2'de şekil hafızalı bir ceket örneği görülmektedir. Tasarımcı Marielle Leenders, ya malzemeye dokuma ile ya da daha sonra bir veya daha fazla dikiş hattı olarak eklenen şekil hafızalı tel içeren kumaşları deneyerek çalışmasını gerçekleştirmiştir. Leenderds'in hareketli tekstilleri, sicaklık farklılıklarına büzüşerek, katlanarak, yapıyı değiştirerek veya yuvarlanarak tepki vermiştir. Şekil hafızalı alaşımlı tel içeren kumaşlar, sıcaklıktaki değişikliklere göre şekil olarak değişmektedir. Bu çalışma ince tel, nikel ve titanyum bazlı bir alaşımdan yapılmıştır. Uygun termal işleme tabi tutulduklarında önceden tanımlanmış bir şekle veya boyuta dönme yeteneği ile planlanan ürün elde edilmiştir [6].
Tasarımı kıyafet mimarlığı olarak tanımlayan Arzu Kaprol 2015 yılında, akıllı giyimin ilk prototiplerinden biri olan; klima değişikliklerine göre fonksiyon değiştiren "Akıllı Ceket" ile yine sektörün öncü hareketleri arasında yerini almıştır. Modacı Arzu Kaprol tasarımı olan kapşonlu akıllı ceket, yaklaşık 1200 gram ağırlığında olup hava durumuna göre şekil değiştirme özelliği bulunmaktadır. Ceketin üzerindeki mikro güneş panelleri sayesinde gün içinde enerji toplayarak vücudu isıtmakta veya soğutmaktadır [7].

Tüketici davranışı, bireylerin ya da grupların istek ve ihtiyaçlarını tatmin etmek için ürünleri, hizmetleri, düşünceleri ya da deneyimleri seçmesi, satın alması, kullanması ya da elden çıkarması ile ilgili süreçleri ve bu süreçleri etkileyen faktörleri inceleyen çalışma alanı olarak tanımlanabilir [8]. Tüketicilerin bir ürünü satın almaya karar vermesine etki edebilecek birçok etken bulunmaktadır. Demografik faktörler (cinsiyet, yaş, meslek, medeni durum, gelir, eğitim düzeyi gibi bireysel nitelikler), marka bağımlılığı, fiyat odaklılığı, satın almanın bir eğlence olduğunu düşünme yapısı, alışveriş yapma bağımlılı̆̆1 (düşünmeden ihtiyacı olup olmadığını bilmeden alışveriş yapma), ürün seçimi için çok fazla alternatif olması ve bu sebeple müşterinin kafa karışıklığı, modayı takip etme veya yeni markaları keşfetme merakı gibi etkenler örnek olarak verilebilir. Günümüz teknolojisinin tüketicileri daha bilinçli ve seçici hale getirmesiyle beraber tüketici davranışlarını tüm yönleriyle tanımlayan çok iyi bir model ile karşılaşamadığımızı görebilmekteyiz. Her şeyden önce tüketici davranışı bir insan davranışı olduğundan, insanı etkileyecek her durum tüketicinin satın alma davranışını da etkilemekte ve dinamik bir süreç olarak doğal ve toplumsal çevreye uyum sağlamak ve ihtiyaçları karşılamak için insanlar sürekli mal veya hizmet satın almaktadırlar. Bireyler, talep ve ihtiyaçlarını karşılayamadığı zaman sorunlar ortaya çıkmakta, bu sorunlar psikolojik ve toplumsal alanlarda yeni uyumlara yol açmakta ve söz konusu uyumların tüketicilerin davranışlarına etki ettiği görülmektedir [9].

Tüketicileri objektif olarak değerlendirebilmek için, kişilerin bazı demografik özeliklere göre nasıl 
tüketim yaptıklarını incelemek gerekir. Demografik özellikler, bireyi belirleyen ve sosyal çevredeki yerini açıklayan, doğuştan gelen fiziksel, sosyal, ekonomik ve coğrafi tutumlarıdır. İnsanları ve toplulukları birbirinden ayıran, aynı zamanda da birbirine bağlayan bu özellikler cinsiyet, yaş, ırk, din, sosyal sınıf, coğrafya ve ailedir. Belirli bir kitlenin dinamik özelliklerini tanımlayan söz konusu demografik özellikler incelenirken, eğitim düzeyi, gelir düzeyleri farklılı̆̆ı gibi özellikler de tüketici davranış analizi açısından o toplulukta önemli sonuçlar ortaya çıkarabilecek özelliklerdir [10].

Tüketicilerin davranışlarına, sahip oldukları bir takım karakterize edici yahut tanımlayıcı özellikleri şekil verebildiğine göre, bu özelliklerin yeni bir ürüne verecekleri tepkilerle olan ilişkisini çözümlemek gerekir. Bu araştırmada, şekil hafızalı teknolojilerin kullanıldığ 1 bir ürün örneği olarak akıllı ceket ürünü için farklı demografik ve ekonomik özelliklerdeki tüketicilerin tepkilerinde meydana gelebilecek olası farklılıklar araştırılmış ve elde edilen sonuçlar değerlendirilmiştir.

\section{MATERYAL VE METOT}

\subsection{Materyal}

Bu çalışmada iklim değişikliğine göre şeklini ve işlevini değiştirebilen akıllı ceket araştırmada örnek ürün olarak seçilmiştir. Çalışmada, akıllı ceketin varsayılan teknik özellikleri yerine, örneklem grubunun daha kolay anlayabileceği tanımlayıcı görsel özellikleri üzerinde açıklama yapılarak ankete başlanmıştır.

Akıllı ceket soğukta; yaka yükselerek enseyi kapatmakta, kapüşon kapanarak kafayı örtmekte, ceket boyu uzayarak vücudu sicak tutmakta ve sirt kısmından 1sıtma sağlamaktadır. Sicakta; yaka kısalmakta, kapüşon açılmakta, ceket boyu kısalmakta, sirt ve bilek kisımları serin tutulmaktadır Şekil hafızalı akıllı giysi varsayımı ile çalışmada ankete konu olan model Şekil 3'te verilmiştir. Görselde, daha önce dijital ceket olarak üretilmiş olan farklı teknik özelliklere sahip bir tasarımın sadece resminden faydalanılmıştır [11].
Araştırmanın amacını gerçekleştirmek üzere İstanbul'da üniversite öğrencilerine uygulanan anket aracılığı ile katılımcıların cinsiyet, yaş, eğitim, medeni hali, doğum yeri, çalışma durumu, ailenin aylık gelir seviyesi (TL), kimle beraber yaşadığı, araba ve ev sahipliği bilgilerine erişilmiştir. Verileri değerlendirmede IBM SPSS 20 programı kullanılmıştır.

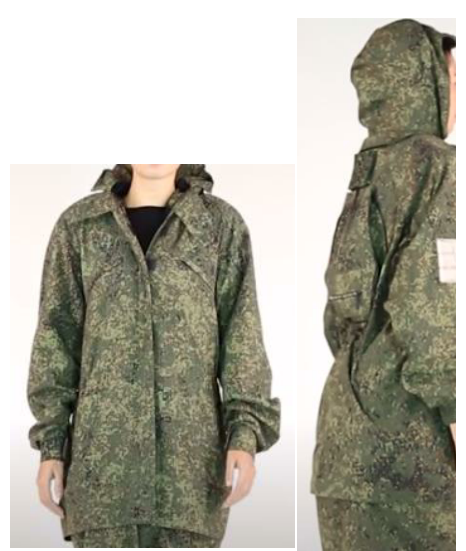

Şekil 3. Akıllı ceket modeli (şekil hafızalı)

Bu çalışmada, 302 kadın ve 304 erkekten oluşan örneklem mevcuttur (3 kişi cinsiyetini belirtmemiştir). Yaş aralığı gruptaki kişi sayısı eşitlenmeye çalışılarak beş ayrı grup (1. grup 18-19 yaş; 2. grup 20 yaş; 3 . grup: 21 yaş; 4 grup: 22 yaş; 5. grup: $23-25$ yaş ve 6 . Grup: $26-30$ yaş) altında toplanmıştır. Yaş ortalaması 21,54 ve standart sapması=2.19'dur. Eğitim seviyesi alt1 farklı kategoride tanımlanmıştır (hazırlık, üniversite 1. sınıf, üniversite 2. sınıf, üniversite 4 . Sınıf, yüksek lisans ve doktora öğrencileri ve diğer). Doğum yeri İstanbul içi ve İstanbul dışı olarak ayrı iki şekilde sınıflandırılmıştır. Medeni durumu incelendiğinde neredeyse tamamının evli olmadığ1 görülmüştür (572 kişi bekar, 28 kişi evli ya da dul). Arabalarının var olup olmadığı, ikamet ettikleri evin sahibi olup olmadıkları ve çalışıp çalışmadıkları evet ve hayır olarak her biri iki şekilde değerlendirilmiştir. Ailenin aylık gelir seviyesi en düşük 1600 TL ve altı ile en yüksek 7200 TL ve üzeri gelir düzeyi olmak üzere 9 ayrı gruba ayrılmıştır. Son olarak, kim ile beraber yaşadıkları sorusu (1) ailem, (2) arkadaşlarım (3) partnerim/eşim (4) tek başına (5) yurtta ve (6) 
akrabalarımla şeklinde ölçülmüștür. Örneklemi oluşturan bu kişileri tanımlayan demografik ve/veya ekonomik değişkenlere ilişkin daha detaylı bilgileri Çizelge 1'de yer almaktadır.

Çizelge 1. Örnekleme ait demografik ve ekonomik özellikler

\begin{tabular}{|c|c|c|c|c|c|c|c|c|c|}
\hline & & & Siklık & Yüzde & & & & Siklik & Yüzde \\
\hline \multirow{3}{*}{ Cinsiyet } & \multirow{2}{*}{$\begin{array}{l}\text { Cevap } \\
\text { verenler }\end{array}$} & Kadın & 302 & 49,6 & \multirow{9}{*}{$\begin{array}{l}\text { Ailenin } \\
\text { aylik } \\
\text { gelir } \\
\text { seviyesi } \\
\text { (TL) }\end{array}$} & \multirow{9}{*}{$\begin{array}{l}\text { Cevap } \\
\text { verenler }\end{array}$} & 1600TL altında & 70 & 11,5 \\
\hline & & Erkek & 304 & 49,9 & & & $1600-2400 \mathrm{TL}$ & 79 & 13,0 \\
\hline & \multicolumn{2}{|c|}{ Cevap vermeyenler } & 3 &, 5 & & & 2401-3200 TL & 77 & 12,6 \\
\hline \multirow{8}{*}{$\begin{array}{l}\text { Yaş } \\
\text { Ort, =21,54 } \\
S, S=2,19\end{array}$} & \multirow{7}{*}{$\begin{array}{l}\text { Cevap } \\
\text { verenler }\end{array}$} & 18-19 & 82 & 13,5 & & & $3201-4000 \mathrm{TL}$ & 78 & 12,8 \\
\hline & & 20 & 113 & 18,6 & & & $4001-4800 \mathrm{TL}$ & 48 & 7,9 \\
\hline & & 21 & 113 & 18,6 & & & $4801-5600 \mathrm{TL}$ & 42 & 6,9 \\
\hline & & 22 & 117 & 19,2 & & & $5601-6400 \mathrm{TL}$ & 42 & 6,9 \\
\hline & & $23-25$ & 112 & 18,4 & & & $6401-7200 \mathrm{TL}$ & 24 & 3,9 \\
\hline & & $26-30$ & 30 & 4,9 & & & 7200TL üzeri & 58 & 9,5 \\
\hline & & Toplam & 567 & 93,1 & \multicolumn{3}{|c|}{ Cevap vermeyenler } & 91 & 14,9 \\
\hline & \multicolumn{2}{|c|}{ Cevap vermeyenler } & 42 & 6,9 & & & & & \\
\hline \multirow{7}{*}{ Eğitim } & \multirow{6}{*}{$\begin{array}{l}\text { Cevap } \\
\text { verenler }\end{array}$} & \begin{tabular}{|l} 
Üniversite 1, sinif \\
\end{tabular} & 45 & 7,4 & \multirow{7}{*}{$\begin{array}{l}\text { Kimle } \\
\text { yaşıyor }\end{array}$} & \multirow{6}{*}{$\begin{array}{l}\text { Cevap } \\
\text { verenler }\end{array}$} & Ailem & 356 & 58,5 \\
\hline & & Üniversite 2, Sınıf & 96 & 15,8 & & & Arkadaşlarım & 94 & 15,4 \\
\hline & & Üniversite 3, Sınıf & 180 & 29,6 & & & Partnerim/Eşim & 16 & 2,6 \\
\hline & & Üniversite 4, Sınıf & 102 & 16,7 & & & Tek başına & 38 & 6,2 \\
\hline & & $\begin{array}{r}\text { Yüksek lisans } \\
\text { veya doktora }\end{array}$ & 128 & 21,0 & & & Yurtta & 82 & 13,5 \\
\hline & & Diğer & 47 & 7,7 & & & Akrabalarımla & 12 & 2,0 \\
\hline & & 11 & 1,8 & & \multicolumn{2}{|c|}{ Cevap vermeyenler } & 11 & 1,8 \\
\hline \multirow{3}{*}{ Doğum yeri } & \multicolumn{2}{|c|}{ Cevap } & 276 & 45,3 & \multirow{3}{*}{ Ev sahipliği } & \multirow{2}{*}{$\begin{array}{l}\text { Cevap } \\
\text { verenler }\end{array}$} & Evi olanlar & 260 & 42,7 \\
\hline & verenler & Diğer & 261 & 42,9 & & & Evi olmayanlar & 266 & 43,7 \\
\hline & \multicolumn{2}{|c|}{ Cevap vermeyenler } & 72 & 11,8 & & \multicolumn{2}{|c|}{ Cevap vermeyenler } & 83 & 13,6 \\
\hline \multirow{3}{*}{$\begin{array}{l}\text { Çalışma } \\
\text { durumu }\end{array}$} & \multirow{2}{*}{$\begin{array}{l}\text { Cevap } \\
\text { verenler }\end{array}$} & Çalışanlar & 140 & 23,0 & \multirow{3}{*}{$\begin{array}{l}\text { Araba } \\
\text { sahipliği }\end{array}$} & \multirow{2}{*}{$\begin{array}{l}\text { Cevap } \\
\text { verenler }\end{array}$} & Arabası olanlar & 99 & 16,3 \\
\hline & & Çalışmayanlar & 438 & 71,9 & & & $\begin{array}{r}\text { Arabas1 } \\
\text { olmayanlar }\end{array}$ & 340 & 55,8 \\
\hline & \multicolumn{2}{|c|}{ Cevap vermeyenler } & 31 & 5,1 & & \multicolumn{2}{|c|}{ Cevap vermeyenler } & 170 & 27,9 \\
\hline \multicolumn{3}{|c|}{ Toplam katılımc1 sayısı } & & & & & & 609 & 100,0 \\
\hline
\end{tabular}

Ort: Ortalama, Std. Sapma: Standart sapma, Std. hata ort.: Standart hata ortalaması, Sd: Serbestlik derecesi

\section{2. Ölçümler}

Araştırma değişkenlerinden cinsiyet, eğitim, medeni hal, çalışma durumu, gelir seviyesi, kim ile beraber yaşadığ1, ev sahipliği ve araba sahipliği kategorik olarak ölçülmüştür. Yaş değişkeni ve doğum yeri açık uçlu soru formu kullanılarak cevap istenmiştir. Daha sonra yaş değişkeni için açık uçlu soru cevapları kategorik forma dönüştürülüp 6 grup olarak analizlerde kullanılırken, doğum yeri değişkeni de İstanbul ve diğer şehirler şeklinde iki ayrı kategori altında toplanarak analizlere dahil edilmiştir.

Örneklem karakteristiklerine göre profili çıkarılan kişilerin akıllı ceket ürünü için davranışsal, duygusal ve bilişsel tepkilerinin nasıl farklılık gösterdiğini anlamak amaçlanmıştır. Davranışsal tepkilerini ölçmek için 3 soruluk satın alma niyeti ölçeği (satın almayı düşünürüm, muhtemelen satın alırım, satın almam mümkün değil) kullanılmıştır. $\mathrm{Bu}$ sorulardan sonuncusu beklenildiği gibi algılanmadığı için elimine edilmiştir. Bu soruların cevaplandırılmasında uç noktaları $1=$ kesinlikle katıliyorum ve 5=kesinlikle katılmiyorum olan 5'li Likert tipi ölçek kullanılmıştır. Bu ölçek Zhang ve Buda tarafından geliştirilen satın alma niyeti ölçeğinden uyarlanmıştır [12].

Duygusal tepkileri 3 kıstas (eğlenceli, sevimli, mutluluk verici) ve bilişsel tepkileri dört kıstastan (kullanışl1, kaliteli, memnun edici, güvenilir) oluşan bir genel soru ile ölçülmüştür. Duygusal ve bilişsel tepkiler için kullanılan ölçeklerdeki değişkenler Bruner ve ark.'larının ölçüm sorularından uyarlanmıştır [13]. Soruda akıllı ceket ürününün sizde uyandırdığı duygu ve düşünceleri aşağ 
2=düşük, 3=orta, 4=yüksek ve 5=çok yüksek ile ifade edilen seçeneklerden birini seçerek belirtiniz denilmiştir. Davranışsal, duygusal ve bilişsel tepkileri ölçmek için kullanılan ölçekler ayrı olarak geçerlilik testi için faktör analizine tabi tutulmuştur ve her birinin güvenilirliğini test etmek için Cronbach's Alpha değerleri hesap edilmiştir. .70 üzerinde bulunan alfa değerleri sorular arası tutarlılığın ölçüsü olarak ölçeklerin güvenilir olduğunu ortaya koymaktadır [14]. Sonuçları Çizelge 2'de bir arada sunulmuştur. Geçerli ve güvenilir olarak kabul edilen ölçekler bir sonraki analizlerde kullanılmıştır.

Çizelge 2. Tüketici tepkileri geçerlilik ve güvenilirlik testi sonuçları

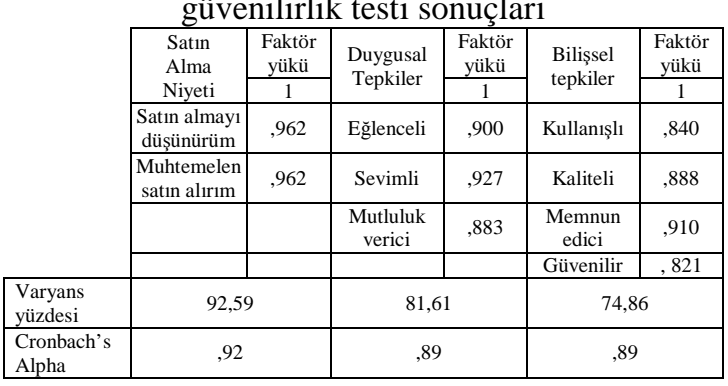

\section{3. İSTATISTIKSEL ANALIZLER}

Anketi uygulama sürecinde 301 kişiye ürün videosu ve 308 kişiye ürün posteri kullanılarak akıllı ceket ürünü hakkında bilgi verilmiştir. Video ve poster olmak üzere iki farklı yöntemle kişilerle bağlantı kurulduğu için ürüne karşı verecekleri tepkilerdeki farklılık bundan kaynaklanabilir. Bu sebeple öncelikle ürün ile ilgili olarak elde edilen davranışsal, duygusal ve bilişsel tepkilerin kullanılan yönteme göre farklılık gösterip göstermediği kontrol edilmiştir.

Çizelge 3'te farklı iki yöntem olan ürün videosu ve ürün posteri grup istatistikleri verilmiştir. Ürün posteri kullanılarak katılımcılara ürün hakkında bilgi verildiğinde ürün videosu kullanıldığı duruma kıyasla katılımcıların satın alma niyeti ve bilişsel tepkiler ortalaması nispeten daha yüksek iken, duygusal tepkiler ortalaması nispeten daha düşüktür. Ortalamalardaki bu fark anlamlı mı değil mi anlamak için yapılan t testi analizi sonuçları Çizelge 4'te yer almaktadır.

Çizelge 3. Uygulanan yönteme göre grup istatistikleri

\begin{tabular}{|c|c|c|c|c|c|}
\hline & Yöntem & $\begin{array}{c}\text { Cevaplayan } \\
\text { sayis1 }\end{array}$ & Ortalama & \begin{tabular}{|c|} 
Std, \\
Sapma
\end{tabular} & $\begin{array}{c}\text { Std, hata } \\
\text { ortalamas1 }\end{array}$ \\
\hline \multirow{2}{*}{$\begin{array}{l}\text { Satın alma } \\
\text { niyeti }\end{array}$} & Ürün posteri & 307 & 3,383 & 1,131 & 0,065 \\
\hline & Ürün videosu & 301 & 3,276 & 1,051 & 0,061 \\
\hline \multirow{2}{*}{\begin{tabular}{|l}
$\begin{array}{l}\text { Duygusal } \\
\text { tepkiler }\end{array}$ \\
\end{tabular}} & Ürün posteri & 308 & 2,612 & 1 & 0,057 \\
\hline & Ürün videosu & 296 & 2,656 & 0,888 & 0,052 \\
\hline & Ürün posteri & 308 & 2,965 & 0,964 & 0,055 \\
\hline tepkiler & Ürün videosu & 296 & 2,939 & 0,871 & 0,051 \\
\hline
\end{tabular}

Ort: Ortalama, Std. Sapma: Standart sapma, Std. hata ort.: Standart hata ortalaması, Sd: Serbestlik derecesi

Çizelge 4'te verilen t testi analizi sonuçları gösteriyor ki; ürün videosu ve ürün posteri olmak üzere iki farklı yöntem bakımından katılımcıların akıllı ceket ürününe karşı olan tepkilerinin hiçbirinde anlamlı bir fark oluşmamıștır. Tüketicilerin bu ürüne olan tepkilerindeki farklılığın nedeni olarak görülemeyeceği için ürün videosu izletilen kişiler ve ürün posterinin gösterildiği kişilerden elde edilen veriler birleştirilmiştir. Bundan sonraki analizlerde toplam $609(308+301)$ kişiden elde edilen verilerden hareketle araştırma sorunsalına cevap aranmıștır.

Çizelge 4. Uygulanan yönteme göre gruplar için t testi analizi

\begin{tabular}{|c|c|c|c|c|c|c|c|c|c|c|}
\hline & \multicolumn{2}{|c|}{$\begin{array}{l}\text { Varyans eşitliği } \\
\text { için levene testi }\end{array}$} & \multicolumn{7}{|c|}{$\mathrm{t}$ testi } \\
\hline & & \multirow[t]{2}{*}{$\mathrm{F}$} & \multirow[t]{2}{*}{ Anlamlılık } & \multirow[t]{2}{*}{$\mathrm{t}$} & \multirow[t]{2}{*}{ sd } & \multirow{2}{*}{$\begin{array}{l}\text { Anlamlılık, } \\
\text { (çift taraflı) }\end{array}$} & \multirow{2}{*}{$\begin{array}{c}\text { Ortalama } \\
\text { fark1 }\end{array}$} & \multirow{2}{*}{$\begin{array}{l}\text { Std, } \\
\text { hata } \\
\text { fark1 }\end{array}$} & \multicolumn{2}{|c|}{$\begin{array}{l}\% 95 \text { fark için } \\
\text { güven aralı̆̆ } 1\end{array}$} \\
\hline & & & & & & & & & En düşük & En yükssek \\
\hline \multirow{2}{*}{$\begin{array}{l}\text { Satın alma } \\
\text { niyeti }\end{array}$} & Varyans eşit & 4,175 & 0,041 & 1,208 & 606 & 0,228 & 0,107 & 0,089 & $-0,067$ & 0,281 \\
\hline & Varyans eșit değil & & & 1,209 & 604,214 & 0,227 & 0,107 & 0,088 & $-0,067$ & 0,281 \\
\hline \multirow{2}{*}{$\begin{array}{l}\text { Duygusal } \\
\text { tepkiler }\end{array}$} & Varyans eşit & 5,736 & 0,017 & $-0,578$ & 602 & 0,564 & $-0,044$ & 0,077 & $-0,196$ & 0,107 \\
\hline & Varyans eşit değil & & & $-0,579$ & 598,228 & 0,563 & $-0,044$ & 0,077 & $-0,195$ & 0,106 \\
\hline \multirow{2}{*}{\begin{tabular}{|l|} 
Bilişsel \\
tepkiler
\end{tabular}} & Varyans eşit & 2,877 & 0,09 & 0,339 & 602 & 0,735 & 0,025 & 0,075 & $-0,122$ & 0,172 \\
\hline & Varyans eșit değil & & & 0,339 & 599,666 & 0,734 & 0,025 & 0,075 & $-0,121$ & 0,172 \\
\hline
\end{tabular}


$\mathrm{Bu}$ araştırmada cevap aranan soru ya demografik ya da ekonomik özellikleri değişik olan tüketicilerin akıllı ceket ürüne karşı olan tepkileri nasıl farklılaşır sorusudur. $\mathrm{Bu}$ yeni teknolojik ürüne olan tepkiler davranışsal (satın alma niyeti), duygusal ve bilişsel olmak üzere üç boyutta değerlendirilmiştir. Sonuç olarak, örneklem birimlerini tanımlamada kullanılan özellikler: cinsiyet, eğitim, doğum yeri, çalışma durumu, ailenin aylık gelir seviyesi, aynı evi kimle paylaştığı, ev ve araba sahipliği araştırmaya dahil edildi. Kişilerin farklılık gösteren demografik ve/veya ekonomik özelliklerine göre akıllı ceket ürünü ile ilgili tepkilerinde farklılık oluşturmadığı her biri için tespit edilmiştir. Fakat sadece eğitim seviyesi farklı olduğunda bu ürüne vereceği tepkilerin farklı olduğu ve bu farklılığın anlamlı olduğu anlaşılmıştır.

2'li kategorize edilen değişkenler: cinsiyet (kadın, erkek), doğum yeri (İ̀stanbul dişı, İstanbul), çalışma durumu (çalışıyor, çalışmıyor), araba (kendi arabası var, kendi arabası yok) ve ev sahipliği (evi var, evi yok). Bu ikili grupların her çifti arasında satın alma niyeti, duygusal ve bilişsel tepkileri bakımından anlamlı bir farklılık olup olmadığ 1 bağımsız t testi ile test edildi. Analizlerde çalışma durumu, araba ve ev sahipliği değişkenlerinin her biri için ayrı olarak gözlemlerden tesadüfi seçim yolu ile grup birim sayısı az olana göre eşitlenip ya da yakın yapıp sonrasında testler uygulandı. İki kategorili diğer değişkenlerde ise grup gözlem sayıları çok yakın sayıdaydı bu yüzden değişiklik yapılmadan test edildiler. 2'den fazla seviyede kategorize edilen yaş, ailenin aylık gelir seviyesi ve aynı evde kimle yaşadığı değişkenleri için tek yönlü varyans analizi ile her biri değişken için farklı grupların satın alma niyeti, duygusal ve bilişsel tepkileri karşılaştırıldı. Ekler bölümünde ilgili analiz sonuçları çizelge gösterimleriyle sunulmuştur. Medeni hal açısından örneklem birimlerinin neredeyse tamamı bekar olunca farklılık testi uygulanamamıştır.

Katılımcıların eğitim durumu altı ayrı seçenekle belirlenmiștir. Katılımcılar arasında üniversite 1. sınıfta 45 kişi, 2. sınıfta 96, 3. sınıfta 180, 4. sınıfta 102 kişi var iken, yüksek lisans veya doktora yaptığını belirten 128 kişi ve "diğer" seçeneğini işaretleyen 47 kişi vardır. Eğitim düzeyleri farklı bu altı grup satın alma niyeti, duygusal ve bilişsel tepkileri açısından anlamlı bir şekilde farklılaşır mı anlayabilmek için Anova analizi uygulanmıştır. Öncelikle her bir gruptaki kişi sayısı eşit veya yakın olacak şekilde, cevap verenler arasından yapılan tesadüfi seçimle kişiler ait oldukları eğitim düzeyindeki gruplara atanmıştır. 44-45'er kişiden oluşan farklı eğitim düzeyinde tanımlanmış bu gruplara ait ortalama, standart sapma vd. istatistiki bilgiler Çizelge 5'te gösterilmiştir.

Çizelge 5'te görüleceği gibi, 1. grupta birinci sınıf, 2. grupta ikinci sınıf, 3. grupta üçüncü sınıf ve 4. grupta dördüncü sınıftaki üniversite öğrencileri yer alırken 5. grupta yüksek lisans ve doktora öğrencileri ve son olarak 6. grupta diğer kişiler olmak üzere altı ayrı grupta farklı eğitim seviyelerinde kişiler tanımlanmıştır. Kişilerin akıllı ceket ürünü için satın alma eğilimi ortalamalarına bakıldığında en düşük puanı 1 . sınıf öğrencileri, en yüksek puanı ise 4. sınıf öğrencileri almıştır. Akıllı ceket ürününe karşı olan duygusal tepkileri ortalama puanlarına gelince; satın alma eğilimlerinin aksine 1. sinıf öğrencilerinde puan daha yüksektir, buna karşın en düşük seviyede olan 2. sınıf öğrencileridir ve 4. sınıf öğrencileri aldığı puanla onları takip etmektedir. Bu ürün için kişilerin bilişsel tepkilerinin hesaplanan ortalama puanları karşılaştırıldığında ise; duygusal tepkilerde olduğu gibi en yüksek 1. sınıf, en düşük 2. sınıf ve bunu takiben ikinci en düşük ortalama puan 4. sinıf öğrencilerine aittir.

Çizelge 5. Eğitim durumuna göre gruplar için tanımlayıcı istatistikleri

\begin{tabular}{|c|c|c|c|c|c|c|c|c|c|}
\hline & \multirow{2}{*}{$\begin{array}{c}\text { Gözlem } \\
\text { sayıs1 }\end{array}$} & \multirow[t]{2}{*}{ Ortalama } & \multirow{2}{*}{$\begin{array}{l}\text { Std, } \\
\text { sapma }\end{array}$} & \multirow[t]{2}{*}{ Std, hata } & \multicolumn{2}{|c|}{$\begin{array}{l}\text { Ortalamalar için } \\
95 \% \text { güven aralığ1 }\end{array}$} & \multirow[t]{2}{*}{ Minimum } & \multirow[t]{2}{*}{ Maksimum } \\
\hline & & & & & & Alt sinir & Üst sınır & & \\
\hline \multirow{3}{*}{$\begin{array}{l}\text { Satın } \\
\text { alma } \\
\text { niyeti }\end{array}$} & 1 & 45 & 2,922 & 0,941 & 0,14 & 2,639 & 3,205 & 1 & 5 \\
\hline & 2 & 45 & 3,389 & 0,947 & 0,141 & 3,104 & 3,673 & 1 & 5 \\
\hline & 3 & 45 & 3,267 & 1,037 & 0,155 & 2,955 & 3,578 & 1 & 5 \\
\hline
\end{tabular}


Akıllı Tekstil Ürünü Olarak Spor Ceket: Yeni Bir Ürüne Yönelik Tüketici Tepkilerinin Örneklem Özelliklerine Göre Değişimi

Çizelge 5 (devam)

\begin{tabular}{|l|c|c|c|c|c|c|c|c|c|}
\hline \multirow{3}{*}{$\begin{array}{l}\text { Satın } \\
\text { alma } \\
\text { niyeti }\end{array}$} & 4 & 45 & 3,678 & 1,018 & 0,152 & 3,372 & 3,984 & 1,5 & 5 \\
\cline { 2 - 10 } & 5 & 45 & 3,489 & 1,084 & 0,162 & 3,163 & 3,815 & 1 & 5 \\
\cline { 2 - 10 } & Total & 45 & 3,044 & 1,06 & 0,158 & 2,726 & 3,363 & 1 & 5 \\
\hline \multirow{5}{*}{$\begin{array}{l}\text { Duygusal } \\
\text { tepkiler }\end{array}$} & 1 & 44 & 3,298 & 1,039 & 0,063 & 3,174 & 3,423 & 1 & 5 \\
\cline { 2 - 10 } & 2 & 44 & 2,401 & 0,905 & 0,137 & 2,126 & 2,677 & 1 & 4,33 \\
\cline { 2 - 10 } & 3 & 45 & 2,615 & 0,935 & 0,139 & 2,334 & 2,896 & 1 & 5 \\
\cline { 2 - 10 } & 5 & 44 & 2,424 & 0,955 & 0,144 & 2,134 & 2,714 & 1 & 4 \\
\cline { 2 - 10 } & 6 & 45 & 2,592 & 0,915 & 0,136 & 2,318 & 2,868 & 1 & 4,33 \\
\cline { 2 - 10 } & Total & 267 & 2,637 & 0,861 & 0,128 & 2,378 & 2,896 & 1 & 4,33 \\
\hline \multirow{5}{*}{$\begin{array}{l}\text { Bilişsel } \\
\text { tepkiler }\end{array}$} & 1 & 44 & 3,114 & 0,901 & 0,055 & 2,504 & 2,722 & 1 & 5 \\
\cline { 2 - 10 } & 2 & 44 & 2,716 & 0,922 & 0,139 & 2,435 & 2,996 & 1 & 4,75 \\
\cline { 2 - 10 } & 4 & 45 & 2,911 & 0,952 & 0,142 & 2,625 & 3,197 & 1 & 5 \\
\cline { 2 - 9 } & 4 & 44 & 2,784 & 0,889 & 0,134 & 2,514 & 3,054 & 1 & 4,5 \\
\cline { 2 - 9 } & 6 & 45 & 3,02 & 0,909 & 0,136 & 2,747 & 3,293 & 1,25 & 4,75 \\
\cline { 2 - 9 } & Total & 267 & 2,961 & 0,943 & 0,141 & 2,678 & 3,244 & 1 & 5 \\
\hline
\end{tabular}

Satın alma niyeti, duygusal ve bilişsel tepkiler olmak üzere üç değişken bakımından farklı eğitim gruplarında olan kişiler ortalama puanları açısından karşılaştırılmıştır. Bu karşılaştırmalarda ortaya çıkan ortalama puanları arasındaki farkların anlamlı bir farklılık olup olmadığı tek yönlü varyans analizi (ANOVA) ile test edilmiştir. Çizelge 6'da gösterilen sonuçlara göre; alt1 grupta toplanmış farklı eğitim seviyesinde olan kişilerin akıllı ceket ürünü için satın alma niyetleri ve duygusal tepkileri anlamlı bir şekilde farklılık gösterirken ( $p=0,005$ ve $p=0,023$ ) bilişsel tepkileri anlamlı bir farklılık göstermemektedir $(\mathrm{p}=0,323)$.

Çizelge 6. Eğitim seviyesine göre gruplar için ANOVA analizi

\begin{tabular}{|l|l|c|c|c|c|c|}
\hline \multicolumn{2}{|c|}{} & $\begin{array}{c}\text { Kareler } \\
\text { toplamı }\end{array}$ & sd & $\begin{array}{c}\text { Ort. } \\
\text { kare }\end{array}$ & F & Anlamlılı, \\
\hline $\begin{array}{l}\text { Satın } \\
\text { alma } \\
\text { niyeti }\end{array}$ & Gruplar aras1 & 17,794 & 5 & 3,559 & 3,448 & 0,005 \\
\cline { 2 - 8 } & Gruplar içi & 272,456 & 264 & 1,032 & & \\
\cline { 2 - 8 } $\begin{array}{l}\text { Duygusal } \\
\text { tepkiler }\end{array}$ & Truplam & 290,249 & 269 & & & \\
\cline { 2 - 8 } & Gruplar içi & 10,431 & 5 & 2,086 & 2,649 & 0,023 \\
\cline { 2 - 8 } & Toplam & 216,008 & 261 & 0,788 & & \\
\hline \multirow{3}{*}{$\begin{array}{l}\text { Bilişsel } \\
\text { tepkiler }\end{array}$} & Gruplar aras1 & 4,827 & 5 & 0,965 & 1,173 & 0,323 \\
\cline { 2 - 8 } & Gruplar içi & 214,915 & 261 & 0,823 & & \\
\cline { 2 - 8 } & 219,742 & 266 & & & \\
\hline
\end{tabular}

Varyans analizinin dayandığı bir varsayım olan varyansların homojenliğini test etmek üzere Levene istatistik testi uygulanmıştır ve sonuçları Çizelge 7'de açıklanmıştır. Buna göre altı farklı eğitim grubu için satın alma niyeti bakımından varyans homojenliği sağlanmıştır $(p=0,312)$, ancak duygusal tepkiler bakımından varyans homojenliği $(\mathrm{p}=0,012)$ elde edilememiştir. Buradan hareketle farklı eğitim seviyelerinde tanımlı altı gruptan hangi iki grup arasında gerek satın alma eğilimleri gerekse duygusal tepkileri açısından anlamlı bir sonuç olduğu araştırılırken post-hoc analizlere başvurulmuştur.

Çizelge 7. Eğitim seviyesine göre gruplar için varyans homojenliği testi

\begin{tabular}{|l|c|c|c|c|}
\hline & $\begin{array}{c}\text { Levene } \\
\text { İstatistiği }\end{array}$ & sd1 & sd2 & Anlamlılık \\
\hline Satın alma niyeti & 1,195 & 5 & 264 &, 312 \\
\hline Duygusal tepkiler & 2,976 & 5 & 261 &, 012 \\
\hline Bilişsel tepkiler &, 568 & 5 & 261 &, 725 \\
\hline
\end{tabular}

Çizelge 8'de farklı eğitim grupları için satın alma eğilimi ortalamaları farkı hangi iki grup arasında anlamlıdır anlayabilmek için yapılan çoklu karşılaştırmada varyans homojenliği testi anlamlı çıktığı için [15] Scheffe testi uygulanmıştır. Uygulanan post-hoc analizi sonucuna göre akıllı ceket ürünü için 4. gruptaki üniversite dördüncü sınıf öğrencilerinin 1. gruptaki birinci sınıf öğrencilerine kiyasla yüksek bir fark gösteren ortalama satın alma niyeti anlamlıdır (I-J=0,756, $\mathrm{p}=0,032)$. Diğer ikili gruplar arasında satın alma 
niyetleri bakımından grup ortalama farkları anlamlı bulunmamıştır.

Çizelge 8. Davranışsal tepkiler için Post-hoc analizi ile grupları çoklu karşılaştırmada Scheffe testi

\begin{tabular}{|c|c|c|c|c|c|c|}
\hline \multirow{2}{*}{$\begin{array}{c}\text { (I) } \\
\text { Eğitim }\end{array}$} & \multirow{2}{*}{$\begin{array}{c}(\mathrm{J}) \\
\text { Eğitim }\end{array}$} & \multirow{2}{*}{\begin{tabular}{|c|}
$\begin{array}{c}\text { Ortalama } \\
\text { fark1 }\end{array}$ \\
$(\mathrm{I}-\mathrm{J})$ \\
\end{tabular}} & \multirow{2}{*}{$\begin{array}{l}\text { Std, } \\
\text { hata }\end{array}$} & \multirow[t]{2}{*}{ Anlamlılık } & \multicolumn{2}{|c|}{$\begin{array}{c}\% \text { 95 Güven } \\
\text { aralığ } 1\end{array}$} \\
\hline & & & & & Alt sinır & Üst sinır \\
\hline \multirow{5}{*}{$\begin{array}{c}\text { 1: üniversite } \\
1 . \text { sınıf }\end{array}$} & 2 & $-0,467$ & 0,214 & 0,449 & \begin{tabular}{|l|}
$-1,185$ \\
\end{tabular} & 0,251 \\
\hline & 3 & $-0,344$ & 0,214 & 0,763 & $-1,062$ & 0,374 \\
\hline & 4 &,$- 756^{*}$ & 0,214 & 0,032 & $-1,474$ & $-0,037$ \\
\hline & 5 & $-0,567$ & 0,214 & 0,224 & $-1,285$ & 0,151 \\
\hline & 6 & $-0,122$ & 0,214 & 0,997 & $-0,84$ & 0,596 \\
\hline \multirow{5}{*}{$\begin{array}{l}\text { 2: üniversite } \\
2 . \sin 1 f\end{array}$} & 1 & 0,467 & 0,214 & 0,449 & $-0,251$ & 1,185 \\
\hline & 3 & 0,122 & 0,214 & 0,997 & $-0,596$ & 0,84 \\
\hline & 4 & $-0,289$ & 0,214 & 0,873 & $-1,007$ & 0,429 \\
\hline & 5 & $-0,1$ & 0,214 & 0,999 & $-0,818$ & 0,618 \\
\hline & 6 & 0,344 & 0,214 & 0,763 & $-0,374$ & 1,062 \\
\hline \multirow{5}{*}{$\begin{array}{l}\text { 3: üniversite } \\
\text { 3. sinif }\end{array}$} & 1 & 0,344 & 0,214 & 0,763 & $-0,374$ & 1,062 \\
\hline & 2 & $-0,122$ & 0,214 & 0,997 & $-0,84$ & 0,596 \\
\hline & 4 & $-0,411$ & 0,214 & 0,596 & $-1,129$ & 0,307 \\
\hline & 5 & $-0,222$ & 0,214 & 0,956 & $-0,94$ & 0,496 \\
\hline & 6 & 0,222 & 0,214 & 0,956 & $-0,496$ & 0,94 \\
\hline \multirow{5}{*}{$\begin{array}{l}\text { 4: üniversite } \\
\text { 4. sinıf }\end{array}$} & 1 &, $756^{*}$ & 0,214 & 0,032 & 0,037 & 1,474 \\
\hline & 2 & 0,289 & 0,214 & 0,873 & $-0,429$ & 1,007 \\
\hline & 3 & 0,411 & 0,214 & 0,596 & $-0,307$ & 1,129 \\
\hline & 5 & 0,189 & 0,214 & 0,978 & $-0,529$ & 0,907 \\
\hline & 6 & 0,633 & 0,214 & 0,124 & $-0,085$ & 1,351 \\
\hline \multirow{5}{*}{ 5: YLS, Dok } & 1 & 0,567 & 0,214 & 0,224 & $-0,151$ & 1,285 \\
\hline & 2 & 0,1 & 0,214 & 0,999 & $-0,618$ & 0,818 \\
\hline & 3 & 0,222 & 0,214 & 0,956 & $-0,496$ & 0,94 \\
\hline & 4 & $-0,189$ & 0,214 & 0,978 & $-0,907$ & 0,529 \\
\hline & 6 & 0,444 & 0,214 & 0,508 & $-0,274$ & 1,162 \\
\hline \multirow{5}{*}{ 6: Diğer } & 1 & 0,122 & 0,214 & 0,997 & $-0,596$ & 0,84 \\
\hline & 2 & $-0,344$ & 0,214 & 0,763 & $-1,062$ & 0,374 \\
\hline & 3 & $-0,222$ & 0,214 & 0,956 & $-0,94$ & 0,496 \\
\hline & 4 & $-0,633$ & 0,214 & 0,124 & $-1,351$ & 0,085 \\
\hline & 5 & $-0,444$ & 0,214 & 0,508 & $-1,162$ & 0,274 \\
\hline
\end{tabular}

*, Ortalama farkı 0,05 düzeyinde anlamlı

Çizelge 9'da farklı eğitim grupları için duygusal tepkilerin ortalamaları farkı hangi iki grup arasında anlamlıdır anlayabilmek için yapılan çoklu karşılaştırmada varyans homojenliği testi anlamlı çıkmadığı için [15] Games-Howell testi uygulanmıştır. Post-hoc analizi sonucuna göre; akıllı ceket ürünü için 1. gruptaki birinci sınıf öğrencilerinin, hem 2. gruptaki ikinci sınıf hem de 4. gruptaki dördüncü sınıftakilere kıyasla yüksek bir fark gösteren ortalama duygusal tepkileri anlamlidir (I-J=0,606, $\mathrm{p}=0,011$ ve $\mathrm{I}-\mathrm{J}=0,583$, $\mathrm{p}=0,023)$. Diğer ikili gruplar arasında duygusal tepkileri bakımından grup ortalama farkları anlamlı bulunmamıştır.
Çizelge 9. Duygusal tepkiler için Post-hoc analizi ile grupları çoklu karşılaştırmada Games-Howell testi

\begin{tabular}{|c|c|c|c|c|c|c|}
\hline \multirow{2}{*}{$\begin{array}{l}\text { (I) } \\
\text { Eğitim }\end{array}$} & \multirow{2}{*}{$\begin{array}{l}(\mathrm{J}) \\
\text { Eğitim }\end{array}$} & \multirow{2}{*}{$\begin{array}{c}\begin{array}{c}\text { Ortalama } \\
\text { fark1 }\end{array} \\
(\mathrm{I}-\mathrm{J}) \\
\end{array}$} & \multirow{2}{*}{$\begin{array}{l}\text { Std. } \\
\text { hata }\end{array}$} & \multirow{2}{*}{ Anlamlılık } & \multicolumn{2}{|c|}{$\begin{array}{c}\text { \% 95 Güven } \\
\text { aralığ } 1\end{array}$} \\
\hline & & & & & Alt sinir & Alt sinır \\
\hline \multirow{5}{*}{$\begin{array}{l}\text { 1: üniversite } \\
1 \text {. sinıf }\end{array}$} & 2 &, $606^{*}$ & 0,176 & 0,011 & 0,093 & 1,119 \\
\hline & 3 & 0,393 & 0,178 & 0,246 & $-0,126$ & 0,912 \\
\hline & 4 &, $583^{*}$ & 0,182 & 0,023 & 0,053 & 1,113 \\
\hline & 5 & 0,415 & 0,176 & 0,182 & $-0,098$ & 0,928 \\
\hline & 6 & 0,37 & 0,17 & 0,255 & $-0,124$ & 0,865 \\
\hline \multirow{5}{*}{$\begin{array}{l}\text { 2: üniversite } \\
2 \text {. sinıf }\end{array}$} & 1 &,$- 606^{*}$ & 0,176 & 0,011 & $-1,119$ & $-0,093$ \\
\hline & 3 & $-0,213$ & 0,195 & 0,883 & $-0,782$ & 0,355 \\
\hline & 4 & $-0,023$ & 0,198 & 1 & $-0,601$ & 0,555 \\
\hline & 5 & $-0,191$ & 0,193 & 0,92 & $-0,753$ & 0,371 \\
\hline & 6 & $-0,235$ & 0,187 & 0,807 & $-0,782$ & 0,311 \\
\hline \multirow{5}{*}{$\begin{array}{l}\text { 3: üniversite } \\
\text { 3. sinıf }\end{array}$} & 1 & $-0,393$ & 0,178 & 0,246 & $-0,912$ & 0,126 \\
\hline & 2 & 0,213 & 0,195 & 0,883 & $-0,355$ & 0,782 \\
\hline & 4 & 0,191 & 0,2 & 0,932 & $-0,393$ & 0,774 \\
\hline & 5 & 0,022 & 0,195 & 1 & $-0,546$ & 0,59 \\
\hline & 6 & $-0,022$ & 0,189 & 1 & $-0,574$ & 0,53 \\
\hline \multirow{5}{*}{$\begin{array}{l}\text { 4: üniversite } \\
\text { 4. sınıf }\end{array}$} & 1 &,$- 583^{*}$ & 0,182 & 0,023 & $-1,113$ & $-0,053$ \\
\hline & 2 & 0,023 & 0,198 & 1 & $-0,555$ & 0,601 \\
\hline & 3 & $-0,191$ & 0,2 & 0,932 & $-0,774$ & 0,393 \\
\hline & 5 & $-0,168$ & 0,198 & 0,957 & $-0,746$ & 0,41 \\
\hline & 6 & $-0,212$ & 0,193 & 0,879 & $-0,775$ & 0,349 \\
\hline \multirow{5}{*}{ 5: YLS, Dok, } & 1 & $-0,415$ & 0,176 & 0,182 & $-0,928$ & 0,098 \\
\hline & 2 & 0,191 & 0,193 & 0,92 & $-0,371$ & 0,753 \\
\hline & 3 & $-0,022$ & 0,195 & 1 & $-0,59$ & 0,546 \\
\hline & 4 & 0,168 & 0,198 & 0,957 & $-0,41$ & 0,746 \\
\hline & 6 & $-0,044$ & 0,187 & 1 & $-0,59$ & 0,501 \\
\hline \multirow{5}{*}{ 6: Diğer } & 1 & $-0,37$ & 0,17 & 0,255 & $-0,865$ & 0,124 \\
\hline & 2 & 0,235 & 0,187 & 0,807 & $-0,311$ & 0,782 \\
\hline & 3 & 0,022 & 0,189 & 1 & $-0,53$ & 0,574 \\
\hline & 4 & 0,213 & 0,193 & 0,879 & $-0,349$ & 0,775 \\
\hline & 5 & 0,044 & 0,187 & 1 & $-0,501$ & 0,59 \\
\hline
\end{tabular}

\section{SONUÇLAR VE ÖNERILER}

Yeni ve yüksek teknoloji içeren ürünlerin başarısında tüketici satın alma davranışlarını belirleyen pek çok etken faktör kendini gösterebilir. Öncesinde ürünün potansiyel alıcısı olabilecek kişileri özelliklerine göre sınıflandırıp ayrıştırmak sonrasında hangi faktörlerden nasıl etkilenirler araştırmak daha anlamlıdır. Yenilikçi bir ürüne ilişkin tüketici tepkilerinin farklı oluşunda hangi demografik ve ekonomik göstergeler belirleyicidir? İşte bu sorunun cevabına göre ayrıştırılan gruplardaki bireylere özelliklerine 
göre daha uygun pazarlama stratejileri yöneltilebilir.

İleri teknolojinin büyük bir ivme kazandığı günümüz yaşamında gelişmiş, fark yaratan, yenilikçi tekstil ürünleri "akıllı" özellikleri ile değer yaratmaktadır. Değişen hava koşulları ve vücut 1sısına göre kullanıcı için konfor yaratabilecek fonksiyonellikte olan akıllı spor ceketler hali hazırda pazara sunulmuştur. Talebin artması ve kullanımın yaygınlaşması için akıllı ceketleri tercih eden kişileri özellikleri bakımından ayrıştırıp, tanımlamak önemlidir.

Kişileri karakterize eden veyahut tanımlayan bir dizi özellik arasından cinsiyet, doğum yeri, yaş, medeni hal ve eğitim düzeyi demografik değişkenleri ile birlikte ailenin aylık gelir seviyesi, aynı evi paylaştığı kişiler, araba ve ev sahipliği, çalışma durumu gibi bazı ekonomik göstergeler bu araştırmada incelenmiştir. Belirtilen bu kriterler düzeyinde farklı gruplarda yer eden katılımc1 kişiler akıllı ceket ürününe karşı gösterdikleri duygusal, bilişsel ve davranışsal eğilimleri bakımından karşılaştırılmıştır. Sadece bireylerin bu yeni ürüne karşı geliştirdikleri tepkilerde anlamlı bir fark yaratan kriter eğitim düzeyleri olmuştur. Eğitim düzeyleri üniversite 1., 2., 3. veya 4. sınıf öğrencisi (veya mezun), yüksek lisans veya doktora öğrencisi olmak üzere tanımlanmıştı. Buna göre, 1. sınıf üniversite öğrencileri ile 4. sınıf üniversite öğrencileri (veya mezun) akıllı spor cekete karşı hem duygusal hem de davranışsal tepkileri anlamlı düzeyde farklı olmuştur. 1. sınıf öğrencileri aynı zamanda 2. sinıftakilerden ürün için gösterdikleri duygusal tepkileri bakımından anlamlı şekilde farklılaşmaktadır. Fakat eğitim düzeyleri farklı olan kişilerin hiçbiri ürüne karşı anlamlı bir fark yaratacak düzeyde değişik bir bilişsel tepki vermemektedir.

Yüksek teknoloji içeren yenilikçi ve akıllı bu ceket ürünü 1. sınıf öğrencileri üzerinde ortalama seviyenin bir miktar üzerinde pozitif duygu ve düşünce uyandırmıştır. Satın alma eğilimleri ise gerek duygusal gerekse bilişsel tepkilerine nazaran daha alt düzeyde seyretmektedir. İlginç olan şu ki duygusal ve bilişsel düzeyde en yüksek pozitif seviyede tepkiyi diğer eğitim grubundaki kişilerle karşılaştırıldığında ise 1 . sınıf öğrencileri göstermiştir. Fakat diğerlerine kıyasla satın alma isteği daha düşük seviyededir. Keza bu farklılık duygusal tepkileri için 2. sınıf ve 4. sınıf (veya mezun) öğrencileri ile davranışsal tepkileri için ise sadece 4. sınıftakilerle karşılaştırmasında anlamlı sonuç vermiştir.

İlk üniversiteye başlamanın mutluluğu, rahatlığı ve heyecanı öğrencilerin "ruh haline" kuşkusuz olumlu katkılarda bulunabilir ve bu pozitif ruh hali yenilikleri bir örneği olarak sıradan olmayan bir ceketin onlarda daha belirgin seviyede güzel duygular uyandırması mümkün olabilir. $\mathrm{Bu}$ anlamda 4. sınıfa gelindiğinde mezun olma, iş beklentileri gibi daha ciddi sorumlulukların fark edildiği dönemdekilerle farklı seviyede bir duygusal tepki göstermesi şaşırtıcı olmamıştır.

Öğrenciler 4. sınıfa geldiklerinde daha çok bir iş deneyimi veya ek gelir edinme amaci ile kısa dönemli (part time vb) işlerde çalışabilmektedir. Belki sınıf düzeyleri arasında ürüne yönelik tepkileri bakımından gelirin anlamlı etkisi görülmemiştir ancak ölçümde katılımcıların kendisi değil ailenin aylık gelir seviyesi ölçülmüştü. Kendi kişisel gelirleri ve gelirlerinin ne kadarını hangi tür harcamalara ayıracağı da önemlidir. Buradan hareketle 1. sınıf öğrencileri daha çok yerleşim yeri ve yeme-içme gibi zaruri ihtiyaçlarına öncelik verebilirken her ne kadar spor ceket ve de akıllı olanını olumlu duygu ve düşüncelerle karşılasa da pahalı olduğu için nispeten satın almayı daha geri plana itebilirler. Ancak önceliklerini sıraya koyan, düzenini nispeten daha iyi oturtmuş ve gelirini muhtemelen artırmış olan dördüncü sınıf öğrencileri bu ürünü almaya daha sicak bakabilmektedir.

Akıllı bir teknolojik ürün olan standartlarından farklılaşan bir ceket örneği için ilgi ve alakaları yüksek olacağı beklentisiyle örneklem profili 18-30 yaş aralığında sınırlandırılmıştı. Fakat ürün fonksiyonelliği açısından hem sağlık hem de ergonomik kullanıma uygunluğu sebebiyle daha 
ileri yaşlardaki kişilerin tercihi de olabilir. Daha ilerleyen yaşlarda kişilerin yenilikleri deneme konusunda nispeten daha çekimser kaldıkları ifade edilmekle beraber günlük yaşamlarını kolaylaştırıcı ürünleri tercih etmeleri de yüksek ihtimal dahilindedir. İlerleyen çalışmalarda farklı yaş grupları da gerek demografik gerekse ekonomik göstergeler ile karakterize edilip bu tarz yenilikçi ve akıllı bir ürüne karşı tepkileri analiz edilmelidir.

\section{KAYNAKLAR}

1. Tekstil Sektöründe Dijital Dönüşüm ve Yeni Nesil Ürünler,

http://www.sanayinindijitaldonusumu.com/teks til-sektorunde-dijital-donusum-ve-yeni-nesilurunler/, Erişim tarihi: Kasım 2020.

2. Erol, A.D., Çetiner, S., 2017. Giyilebilir Elektronik/Akıllı Tekstiller ve Uygulamalar, Kahramanmaraş Sütçü İmam Üniversitesi Mühendislik Bilimleri Dergisi, 20(1), 1-20.

3. Erdem, İ.Ö., Yüksel, E., 2016. Tekstil ve Moda Tasarımına Teknolojik Bir Yaklaşım: Akıllı ve Renk Değiştiren Tekstiller, Yedi: Sanat, Tasarım ve Bilim Dergisi, 16, 87-98, ISSN 13 07-9840.

4. Bedeloğlu, A.Ç., 2011. Şekil Hafızalı Alaşımlar ve Tekstil Malzemelerindeki Uygulamaları, Tekstil ve Mühendis, Y1l: 18, 83, 27-37.

5. Coşkun, E., Oğulata, R.T., 2008. Akıllı Tekstiller ve Genel Özellikleri, Çukurova Üniversitesi Fen Bilimleri Enstitüsü Dergisi, 18-3, 100-109.

6. Bengisu, M., Ferrara, M., 2015. Kinetic Materials Experience, Design and Semantics of Form and Movement, DeSForM 2015, Aesthetics of Interaction: Dynamic, Multisensory, Wise, Topic 2: Multisensory, Conference Paper October 2015, 138-146.

7. https://www.cnnturk.com/video/yasam/diger/m esaj-atan-akilli-ceket, Erişim tarihi: 23.05.2015 (Arzu Kaprol Tasarımı videosu)

8. Odabaşı, Y., Anadolu Üniversitesi Yayını, Yayin No: 2604,
https://docplayer.biz.tr/2770655-Tuketicidavranislari.html, Erişim tarihi: Aralık 2020.

9. Yeniçeri, T., Özal, H., 2016. Tüketici Karar Verme Tarzlarının Cinsiyet Kimliğine Göre İncelenmesi, Pazarlama ve Pazarlama Araştırmaları Dergisi, Sayı: 18, 135-168.

10.Tekvar, S.O., 2016. Tüketici Davranışlarının Demografik Özelliklere Göre Tanımlanması, İnsan ve Toplum Bilimleri Araștırmaları Dergisi, 5(6), 1601-1616, http://www.itobiad.com/tr/download/articlefile/222603.

11.Arzu Kaprol Digital Jacket for Vodafone, https://youtu.be/c4xnkpglRx8, Erişim tarihi: Şubat 2021.

12.Zhang, Y., Buda, R., 1999. Moderating Effects of Need for Cognition on Responses to Positively Versus Negatively Framed Advertising Messages, Journal of Advertising, $28(2),-15$.

13. Bruner, G.C., Hensel, P.J., James, K.E., 2005. Marketing Scale Handbook, a Compilation of Multi-item Measures for Consumer Behavior and Advertising. Chicago, Illinois USA: American Marketing Association. 4,33,41,62, $66,73,83,84,99$.

14. Nunnally, J.C., 1978. Psychometric Theory. NY: McGraw-Hill, 701.

15. Kayri, M., 2009. Araştırmalarda Gruplar Arası Farkın Belirlenmesine Yönelik Çoklu Karşılaştırma (Post-Hoc) Teknikleri, Fırat Üniversitesi Sosyal Bilimler Dergisi, 19(1), 51-64.

\section{EKLER}

Çizelge 9.1. Cinsiyete göre gruplar için tanımlayıcı istatistikler

\begin{tabular}{|l|c|c|c|r|c|}
\hline & CINSIYET & N & Ort, & $\begin{array}{c}\text { Std, } \\
\text { sapma }\end{array}$ & $\begin{array}{c}\text { Std, hata } \\
\text { ort, }\end{array}$ \\
\hline \multirow{2}{*}{$\begin{array}{l}\text { Satın alma } \\
\text { niyeti }\end{array}$} & Kadın & 302 & 3,344 & 1,156 &, 066 \\
\cline { 2 - 6 } & Erkek & 303 & 3,321 & 1,038 &, 059 \\
\hline \multirow{2}{*}{$\begin{array}{l}\text { Duygusal } \\
\text { tepkiler }\end{array}$} & Kadın & 299 & 2,614 &, 972 &, 056 \\
\cline { 2 - 6 } & Erkek & 302 & 2,654 &, 926 &, 053 \\
\hline \multirow{2}{*}{$\begin{array}{l}\text { Bilişșel } \\
\text { tepkiler }\end{array}$} & Kadın & 299 & 2,925 &, 944 &, 055 \\
\cline { 2 - 6 } & Erkek & 302 & 2,973 &, 896 &, 052 \\
\hline
\end{tabular}


Akıllı Tekstil Ürünü Olarak Spor Ceket: Yeni Bir Ürüne Yönelik Tüketici Tepkilerinin Örneklem Özelliklerine Göre Değişimi

Çizelge 9.2. Cinsiyete göre gruplar için bağımsız t testi

\begin{tabular}{|c|c|c|c|c|c|c|c|c|c|c|}
\hline & \multicolumn{2}{|c|}{ Levene's Test } & \multicolumn{7}{|c|}{ t-test istatistikleri } \\
\hline & & \multirow{2}{*}{$\mathrm{F}$} & \multirow{2}{*}{ Anlamlılık } & \multirow{2}{*}{$\mathrm{t}$} & \multirow{2}{*}{ sd } & \multirow{2}{*}{$\begin{array}{l}\text { Anlamlılık } \\
\text { (2 taraflı) }\end{array}$} & \multirow{2}{*}{$\begin{array}{l}\text { Ortalama } \\
\text { fark1 }\end{array}$} & \multirow{2}{*}{$\begin{array}{c}\text { Std, hata } \\
\text { fark1 }\end{array}$} & \multicolumn{2}{|c|}{$\% 95$ Güven aralığ 1} \\
\hline & & & & & & & & & En düşük & En yüksek \\
\hline \multirow{2}{*}{$\begin{array}{l}\text { Satın alma } \\
\text { niyeti }\end{array}$} & $\begin{array}{l}\text { Varyanslar } \\
\text { eşit } \\
\end{array}$ & 3,543 & ,060 & ,254 & 603 & 800 & ,023 & ,089 &,- 152 & 197 \\
\hline & $\begin{array}{l}\text { Varyanslar } \\
\text { eşit değil }\end{array}$ & & & ,254 & 594,8 & ,800 & ,023 & ,089 &,- 152 & ,198 \\
\hline \multirow{2}{*}{$\begin{array}{l}\text { Duygusal } \\
\text { tepkiler }\end{array}$} & $\begin{array}{l}\text { Varyanslar } \\
\text { eşit }\end{array}$ & 644 & ,423 &,- 513 & 599 & 608, &,- 040 & ,077 &,- 192 & ,112 \\
\hline & $\begin{array}{l}\text { Varyanslar } \\
\text { eşit değil }\end{array}$ & & &,- 513 & 596,9 & 608, &,- 040 & 077 &,- 192 & , 112 \\
\hline \multirow{2}{*}{$\begin{array}{l}\text { Bilişsel } \\
\text { tepkiler }\end{array}$} & $\begin{array}{l}\text { Varyanslar } \\
\text { eşit }\end{array}$ & 1,410 & ,235 &,- 642 & 599 &, 521 &,- 048 & ,075 &,- 196 & 099 \\
\hline & $\begin{array}{l}\text { Varyanslar } \\
\text { eşit değil }\end{array}$ & & &,- 642 & 596,7 & ,521 &,- 048 & ,075 &,- 196 & ,099 \\
\hline
\end{tabular}

Çizelge 10.1. Yaş değişkenine göre gruplar için tanımlayıcı istatistikler

\begin{tabular}{|c|c|c|c|c|c|c|c|c|c|}
\hline \multirow{2}{*}{\multicolumn{2}{|c|}{ YAŞ }} & \multirow{2}{*}{$\mathrm{N}$} & \multirow{2}{*}{ Ort } & \multirow{2}{*}{ Std. sapma } & \multirow{2}{*}{ Std. hata } & \multicolumn{2}{|c|}{ \% 95 Güven aralığı } & \multirow{2}{*}{ Min } & \multirow{2}{*}{ Max } \\
\hline & & & & & & En düşük & En yüksek & & \\
\hline \multirow{7}{*}{ Satın alma niyeti } & $18-19$ & 30 & 3,250 & ,998 & 182 & 2,877 & 3,623 & 1,00 & 5,00 \\
\hline & 20 & 30 & 3,450 & 1,020 & 186 & 3,069 & 3,831 & 1,00 & 5,00 \\
\hline & 21 & 30 & 3,167 & 1,053 & ,192 & 2,773 & 3,556 & 1,00 & 5,00 \\
\hline & 22 & 30 & 3,433 & 1,158 & 211 & 3,001 & 3,866 & 1,00 & 5,00 \\
\hline & $23-25$ & 30 & 3,433 & 1,097 & 200 & 3,024 & 3,843 & 1,00 & 5,00 \\
\hline & $26-30$ & 30 & 3,417 & 1,115 & 203 & 3,000 & 3,833 & 1,00 & 5,00 \\
\hline & Toplam & 180 & 3,358 & 1,065 &, 079 & 3,202 & 3,515 & 1,00 & 5,00 \\
\hline \multirow{7}{*}{ Duygusal tepkiler } & $18-19$ & 29 & 2,782 & 1,085 & ,201 & 2,370 & 3,194 & 1,00 & 5,00 \\
\hline & 20 & 30 & 2,656 & 973 & , 178 & 2,292 & 3,019 & 1,00 & 5,00 \\
\hline & 21 & 30 & 2,678 & ,903 &, 165 & 2,340 & 3,015 & 1,00 & 5,00 \\
\hline & 22 & 29 & 2,793 & ,902 & , 167 & 2,450 & 3,136 & 1,00 & 4,33 \\
\hline & $23-25$ & 30 & 2,750 & ,919 &, 168 & 2,407 & 3,093 & 1,00 & 4,67 \\
\hline & $26-30$ & 29 & 2,529 & 936 & 174 & 2,172 & 2,885 & 1,00 & 4,33 \\
\hline & Toplam & 177 & 2,698 & 945 & 071 & 2,557 & 2,838 & 1,00 & 5,00 \\
\hline \multirow{7}{*}{ Bilişsel tepkiler } & $18-19$ & 29 & 3,259 & 912 & , 169 & 2,912 & 3,606 & 1,25 & 5,00 \\
\hline & 20 & 30 & 2,925 & 859 & , 157 & 2,604 & 3,246 & 1,00 & 5,00 \\
\hline & 21 & 30 & 2,917 & 1,053 & 192 & 2,523 & 3,310 & 1,00 & 5,00 \\
\hline & 22 & 29 & 3,060 & 977 &, 181 & 2,689 & 3,432 & 1,00 & 4,75 \\
\hline & $23-25$ & 30 & 3,106 & ,901 & ,164 & 2,769 & 3,442 & 1,00 & 5,00 \\
\hline & $26-30$ & 29 & 2,784 & 1,103 & ,205 & 2,365 & 3,204 & 1,00 & 4,75 \\
\hline & Toplam & 177 & 3,008 & 970 &, 073 & 2,864 & 3,152 & 1,00 & 5,00 \\
\hline
\end{tabular}

Çizelge 10.2. Yaş değişkenine göre gruplar için tek yönlü varyans analizi

\begin{tabular}{|c|c|c|c|c|c|c|}
\hline \multicolumn{7}{|c|}{ ANOVA } \\
\hline & & $\begin{array}{l}\text { Kareler } \\
\text { toplamı }\end{array}$ & sd & $\begin{array}{c}\text { Ort, } \\
\text { karesi }\end{array}$ & F & Anlamlılik \\
\hline \multirow{3}{*}{$\begin{array}{l}\text { Satın alma } \\
\text { niyeti }\end{array}$} & Gruplar aras1 & 2,146 & 5 &, 429 &, 372 & \multirow{3}{*}{,868 } \\
\hline & Grup içi & 200,99 & 174 & 1,155 & & \\
\hline & Toplam & 203,14 & 179 & & & \\
\hline \multirow{3}{*}{$\begin{array}{l}\text { Duygusal } \\
\text { tepkiler }\end{array}$} & Gruplar aras 1 & 1,44 & 5 & ,289 & ,317 & \multirow{3}{*}{,902 } \\
\hline & Gruplar içi & 155,86 & 171 & 911 & & \\
\hline & Toplam & 157,30 & 176 & & & \\
\hline \multirow{3}{*}{$\begin{array}{l}\text { Bilişssel } \\
\text { tepkiler }\end{array}$} & Gruplar aras1 & 4,09 & 5 & 818 & 868 & \multirow{3}{*}{, 504} \\
\hline & Gruplar icin & 161,19 & 171 & 943 & & \\
\hline & Toplam & 165,29 & 176 & & & \\
\hline
\end{tabular}

Çizelge 11.1. Doğum yerine göre gruplar için tanımlayıcı istatistikler

\begin{tabular}{|l|l|c|c|c|c|}
\hline & Doğum Yeri & $\mathrm{N}$ & Ort. & $\begin{array}{c}\text { Std. } \\
\text { sapma }\end{array}$ & Std. hata ort. \\
\hline $\begin{array}{l}\text { Satın alma } \\
\text { niyeti }\end{array}$ & $\begin{array}{l}\text { İstanbul } \\
\text { diş1 }\end{array}$ & 260 & 3,342 & 1,079 &, 067 \\
\cline { 2 - 6 } İstanbul & 276 & 3,328 & 1,116 &, 067 \\
\hline $\begin{array}{l}\text { Duygusal } \\
\text { tepkiler }\end{array}$ & $\begin{array}{l}\text { İstanbul } \\
\text { dış1 }\end{array}$ & 259 & 2,623 &, 909 &, 056 \\
\cline { 2 - 6 } & İstanbul & 273 & 2,691 &, 969 &, 059 \\
\hline Bilişsel \\
tepkiler
\end{tabular}


Çizelge 11.2. Doğum yerine göre gruplar için bağımsız t testi

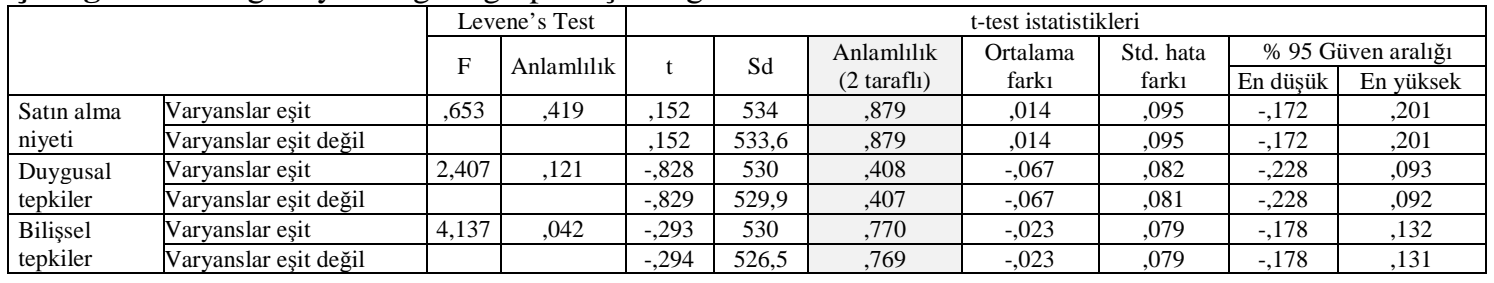

Çizelge 12.1. Çalışma durumuna göre gruplar için tanımlayıcı istatistikler

\begin{tabular}{|c|c|c|c|c|c|}
\hline & Çalışma Durumu & $\mathrm{N}$ & Ort, & $\begin{array}{c}\text { Std, } \\
\text { sapma }\end{array}$ & $\begin{array}{l}\text { Std, hata } \\
\text { ort, }\end{array}$ \\
\hline \multirow{2}{*}{$\begin{array}{l}\text { Satın alma } \\
\text { niyeti }\end{array}$} & Çalışıyor & 140 & 3,17 & 1,155 &, 098 \\
\hline & Çalışmıyor & 139 & 3,36 & 1,054 & ,089 \\
\hline \multirow{2}{*}{$\begin{array}{l}\text { Duygusal } \\
\text { tepkiler }\end{array}$} & Çalışıyor & 139 & 2,75 & ,987 &, 084 \\
\hline & Çalışmıyor & 136 & 2,65 & ,989 & 085 \\
\hline \multirow{2}{*}{$\begin{array}{l}\text { Bilişsel } \\
\text { tepkiler }\end{array}$} & Çalışıyor & 139 & 3,04 & 1,007 &, 085 \\
\hline & Çalışmıyor & 136 & 2,91 & ,915 & 078 \\
\hline
\end{tabular}

Çizelge 12.2. Çalışma durumuna göre gruplar için bağımsız t testi

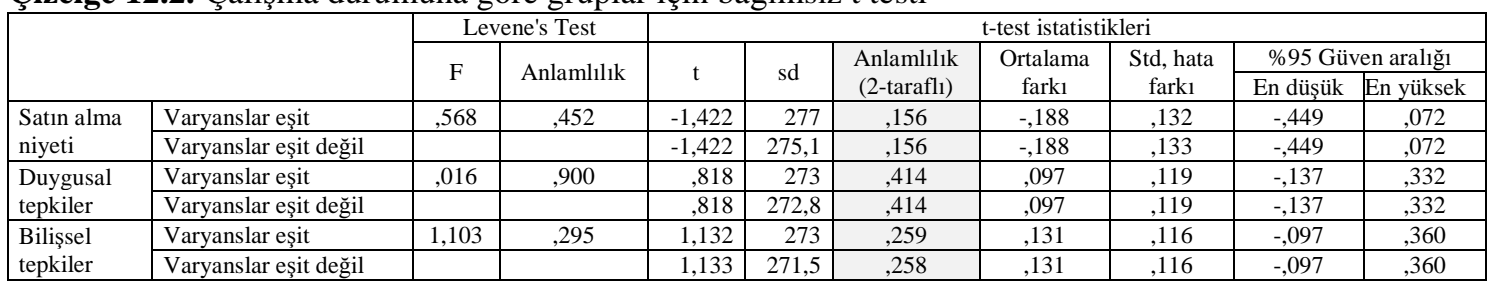

Çizelge 13.1. Gelire göre gruplar için tanımlayıcı istatistikler

\begin{tabular}{|c|c|c|c|c|c|c|c|c|c|}
\hline & \multirow{2}{*}{ Gelir (TL) } & \multirow{2}{*}{$\mathrm{N}$} & \multirow{2}{*}{ Ort. } & \multirow{2}{*}{ Std. sapma } & \multirow{2}{*}{ Std. hata } & \multicolumn{2}{|c|}{$\% 95$ güven aralığ1 } & \multirow{2}{*}{ Min. } & \multirow{2}{*}{ Max. } \\
\hline & & & & & & En düșük & En yüksek & & \\
\hline \multirow{9}{*}{$\begin{array}{l}\text { Satın } \\
\text { alma } \\
\text { niyeti }\end{array}$} & 1600 -altında & 24 & 3,625 & 0,875 & 0,179 & 3,255 & 3,995 & 2,00 & 5,00 \\
\hline & $1601-2400$ & 24 & 3,271 & 1,198 & 0,244 & 2,765 & 3,777 & 1,00 & 5,00 \\
\hline & $2401-3200$ & 24 & 3,458 & 1,112 & 0,227 & 2,989 & 3,928 & 1,00 & 5,00 \\
\hline & $3201-4000$ & 24 & 3,417 & 1,435 & 0,293 & 2,811 & 4,022 & 1,00 & 5,00 \\
\hline & $4001-4800$ & 24 & 3,646 & 0,840 & 0,172 & 3,291 & 4,001 & 2,00 & 5,00 \\
\hline & $4801-5600$ & 24 & 3,500 & 1,043 & 0,213 & 3,060 & 3,940 & 1,00 & 5,00 \\
\hline & $5601-6400$ & 24 & 3,750 & 1,198 & 0,245 & 3,244 & 4,256 & 1,00 & 5,00 \\
\hline & $6401-7200$ & 24 & 3,292 & 1,103 & 0,225 & 2,826 & 3,757 & 1,50 & 5,00 \\
\hline & Toplam & 192 & 3,495 & 1,106 & 0,080 & 3,337 & 3,652 & 1,00 & 5,00 \\
\hline \multirow{9}{*}{$\begin{array}{l}\text { Duygusal } \\
\text { tepkiler }\end{array}$} & 1600-altında & 24 & 2,500 & 0,993 & 0,203 & 2,081 & 2,919 & 1,00 & 4,33 \\
\hline & $1601-2400$ & 24 & 2,542 & 0,861 & 0,176 & 2,178 & 2,905 & 1,00 & 4,33 \\
\hline & $2401-3200$ & 24 & 2,625 & 0,903 & 0,184 & 2,244 & 3,006 & 1,00 & 5,00 \\
\hline & $3201-4000$ & 24 & 2,542 & 0,900 & 0,184 & 2,162 & 2,922 & 1,00 & 4,33 \\
\hline & $4001-4800$ & 24 & 2,556 & 0,838 & 0,171 & 2,202 & 2,909 & 1,00 & 3,67 \\
\hline & $4801-5600$ & 24 & 2,208 & 0,911 & 0,186 & 1,824 & 2,593 & 1,00 & 4,00 \\
\hline & 5601-6400 & 23 & 2,594 & 1,141 & 0,238 & 2,101 & 3,088 & 1,00 & 5,00 \\
\hline & 6401-7200 & 24 & 2,708 & 1,189 & 0,243 & 2,206 & 3,210 & 1,00 & 5,00 \\
\hline & Toplam & 191 & 2,534 & 0,965 & 0,070 & 2,396 & 2,672 & 1,00 & 5,00 \\
\hline \multirow{9}{*}{$\begin{array}{l}\text { Bilişsel } \\
\text { tepkiler }\end{array}$} & 1600-altında & 24 & 2,736 & 0,815 & 0,166 & 2,392 & 3,080 & 1,00 & 3,75 \\
\hline & $1601-2400$ & 24 & 3,042 & 0,836 & 0,171 & 2,689 & 3,395 & 1,00 & 4,75 \\
\hline & $2401-3200$ & 24 & 2,865 & 0,791 & 0,161 & 2,531 & 3,198 & 1,50 & 5,00 \\
\hline & $3201-4000$ & 24 & 2,764 & 0,892 & 0,182 & 2,387 & 3,141 & 1,00 & 4,50 \\
\hline & $4001-4800$ & 24 & 2,771 & 0,831 & 0,170 & 2,420 & 3,122 & 1,00 & 4,25 \\
\hline & $4801-5600$ & 24 & 2,604 & 1,040 & 0,212 & 2,165 & 3,043 & 1,00 & 5,00 \\
\hline & $5601-6400$ & 23 & 2,935 & 1,042 & 0,217 & 2,484 & 3,386 & 1,25 & 5,00 \\
\hline & $6401-7200$ & 24 & 3,021 & 1,063 & 0,217 & 2,572 & 3,470 & 1,00 & 5,00 \\
\hline & Toplam & 191 & 2,842 & 0,913 & 0,066 & 2,711 & 2,972 & 1,00 & 5,00 \\
\hline
\end{tabular}


Akıllı Tekstil Ürünü Olarak Spor Ceket: Yeni Bir Ürüne Yönelik Tüketici Tepkilerinin Örneklem Özelliklerine Göre Değişimi

Çizelge 13.2. Gelire göre gruplar için tek yönlü varyans analizi

\begin{tabular}{|c|c|c|c|c|c|c|}
\hline \multicolumn{7}{|c|}{ ANOVA } \\
\hline & & Kareler toplamı & sd & Ort, karesi & $\mathrm{F}$ & Anlamlılık \\
\hline \multirow{3}{*}{ Satın alma niyeti } & Gruplar arası & 4,891 & 7 & 0,699 & 0,562 & 0,786 \\
\hline & Gruplar içi & 228,604 & 184 & 1,242 & & \\
\hline & Toplam & 233,495 & 191 & & & \\
\hline \multirow{3}{*}{$\begin{array}{l}\text { Duygusal } \\
\text { tepkiler }\end{array}$} & Gruplar aras1 & 3,599 & 7 & 0,514 & 0,542 & 0,802 \\
\hline & Gruplar içi & 173,486 & 183 & 0,948 & & \\
\hline & Toplam & 177,084 & 190 & & & \\
\hline \multirow{3}{*}{$\begin{array}{l}\text { Bilisssel } \\
\text { tepkiler }\end{array}$} & Gruplar arası & 3,829 & 7 & 0,547 & 0,647 & 0,716 \\
\hline & Gruplar içi & 154,637 & 183 & 0,845 & & \\
\hline & Toplam & 158,466 & 190 & & & \\
\hline
\end{tabular}

Çizelge 14.1. Kimle yaşadığına göre gruplar için tanımlayıcı istatistikleri

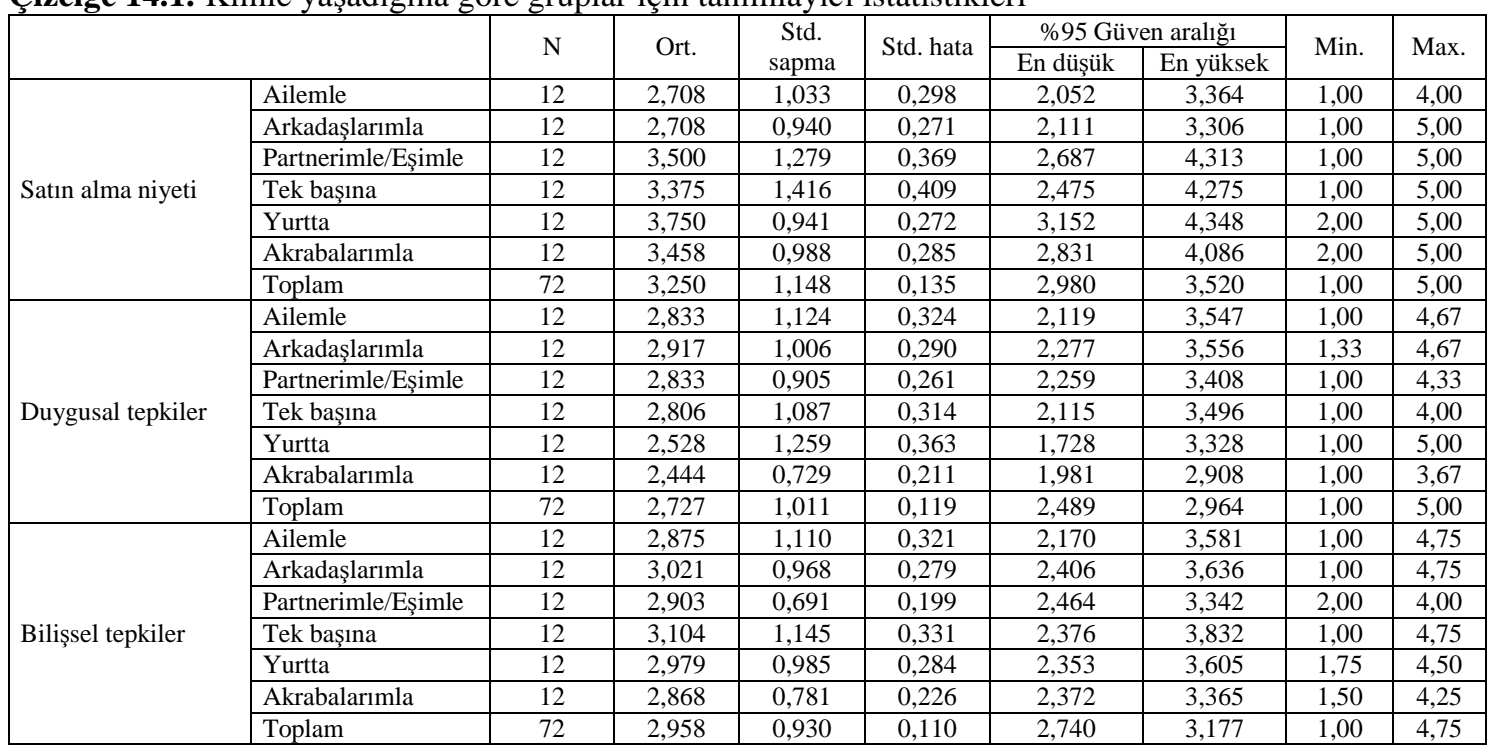

Çizelg14.2. Kimle yaşadığına göre gruplar için tek yönlü varyans analizi

\begin{tabular}{|c|c|c|c|c|c|c|}
\hline \multicolumn{7}{|c|}{ ANOVA } \\
\hline & & Kareler toplamı & sd & Ortalama kare & $\mathrm{F}$ & Anlamlllık \\
\hline \multirow{3}{*}{ Satın alma niyeti } & Gruplar aras1 & 11,500 & 5 & 2,300 & 1,851 & 0,115 \\
\hline & Gruplar içi & 82,000 & 66 & 1,242 & & \\
\hline & Toplam & 93,500 & 71 & & & \\
\hline \multirow{3}{*}{ Duygusal tepkiler } & Gruplar arası & 2,211 & 5 & 0,442 & 0,415 & 0,837 \\
\hline & Gruplar içi & 70,306 & 66 & 1,065 & & \\
\hline & Toplam & 72,517 & 71 & & & \\
\hline \multirow{3}{*}{ Bilişsel tepkiler } & Gruplar arası & 0,525 & 5 & 0,105 & 0,114 & 0,989 \\
\hline & Gruplar içi & 60,947 & 66 & 0,923 & & \\
\hline & Toplam & 61,472 & 71 & & & \\
\hline
\end{tabular}

Çizelge 15.1. Ev sahipliğine göre gruplar için tanımlayıcı istatistikleri

\begin{tabular}{|l|l|c|c|c|c|}
\hline & Ev Sahipliği & N & Ort. & Std. Sapma & Std. Hata Ort. \\
\hline \multirow{2}{*}{$\begin{array}{l}\text { Satın alma } \\
\text { niyeti }\end{array}$} & Varyans eşit & 260 & 3,346 & 1,095 & 0,068 \\
\cline { 2 - 5 } & Varyans Eşit Değil & 265 & 3,292 & 1,085 & 0,067 \\
\hline \multirow{2}{*}{$\begin{array}{l}\text { Duygusal } \\
\text { Tepkiler }\end{array}$} & Varyans eşit & 256 & 2,643 & 0,938 & 0,059 \\
\cline { 2 - 6 } $\begin{array}{l}\text { Bilişsel } \\
\text { Tepkiler }\end{array}$ & Varyans Eşit Değil & 265 & 2,598 & 0,964 & 0,059 \\
\cline { 2 - 6 } & Varyans eşit & 256 & 2,919 & 0,950 & 0,059 \\
\hline
\end{tabular}


Çizelge 15.2. Ev sahipliğine göre gruplar için bağımsız t testi

\begin{tabular}{|c|c|c|c|c|c|c|c|c|c|c|}
\hline & & \multicolumn{2}{|c|}{ Levene's test } & \multicolumn{7}{|c|}{ t-test istatistikleri } \\
\hline & & & & \multirow{2}{*}{$\mathrm{t}$} & \multirow{2}{*}{ sd } & \multirow{2}{*}{$\begin{array}{c}\text { Anlamlilık } \\
\text { (2-taraflı) }\end{array}$} & \multirow{2}{*}{$\begin{array}{l}\text { Ort, } \\
\text { Fark1 }\end{array}$} & \multirow{2}{*}{$\begin{array}{l}\text { Std, hata } \\
\text { ort, }\end{array}$} & \multicolumn{2}{|c|}{$\% 95$ güvenilirlik } \\
\hline & & $\mathrm{F}$ & Anlamlilık & & & & & & En düșük & En yüksek \\
\hline Satın alma & Varyans eşit & 0,145 & 0,704 & 0,565 & 523 & 0,573 & 0,054 & 0,095 & $-0,133$ & 0,240 \\
\hline niyeti & Varyans eşit değil & & & 0,565 & 522,583 & 0,573 & 0,054 & 0,095 & $-0,133$ & 0,241 \\
\hline Duygusal & Varyans esit & 0,079 & 0,778 & 0,541 & 519 & 0,589 & 0,045 & 0,084 & $-0,119$ & 0,209 \\
\hline tepkiler & Varyans eşit değil & & & 0,541 & 518,975 & 0,588 & 0,045 & 0,083 & $-0,119$ & 0,209 \\
\hline Bilişsel & Varyans eşit & 0,755 & 0,385 & $-0,542$ & 519 & 0,588 & $-0,044$ & 0,080 & $-0,202$ & 0,115 \\
\hline tepkiler & Varyans eşit değil & & & $-0,541$ & 513,475 & 0,589 & $-0,044$ & 0,081 & $-0,202$ & 0,115 \\
\hline
\end{tabular}

Çizelge 16.1. Araba sahipliğine göre gruplar için tanımlayıcı istatistikleri

\begin{tabular}{|l|l|c|c|c|c|}
\hline & Araba Sahipliği & $\mathrm{N}$ & Ort. & Std. sapma & Std. hata ort. \\
\hline \multirow{2}{*}{ Satın alma niyeti } & Kendi arabası var & 99 & 3,444 & 1,129 & 0,114 \\
\cline { 2 - 6 } & Kendi arabası yok & 99 & 3,242 & 0,996 & 0,100 \\
\hline \multirow{2}{*}{$\begin{array}{l}\text { Duygusal } \\
\text { tepkiler }\end{array}$} & Kendi arabası var & 99 & 2,596 & 0,901 & 0,091 \\
\cline { 2 - 6 } & Kendi arabası yok & 98 & 2,580 & 0,941 & 0,095 \\
\hline \multirow{2}{*}{ Bilişsel tepkiler } & Kendi arabası var & 99 & 2,835 & 0,960 & 0,096 \\
\cline { 2 - 6 } & Kendi arabası yok & 98 & 2,983 & 0,907 & 0,092 \\
\hline
\end{tabular}

Çizelge 16.1. Araba sahipliğine göre gruplar için bağımsız t testi

\begin{tabular}{|c|c|c|c|c|c|c|c|c|c|c|}
\hline & & \multicolumn{2}{|c|}{ Levene's Test } & \multicolumn{7}{|c|}{ t-test } \\
\hline & & \multirow{2}{*}{$\mathrm{F}$} & \multirow{2}{*}{ Anlamlılık } & \multirow{2}{*}{$\mathrm{t}$} & \multirow{2}{*}{ sd } & \multirow{2}{*}{$\begin{array}{l}\text { Anlamlılık } \\
\text { (2 tarafli) }\end{array}$} & \multirow{2}{*}{$\begin{array}{l}\text { Ort. } \\
\text { fark1 }\end{array}$} & \multirow{2}{*}{$\begin{array}{l}\text { Std. hata } \\
\text { fark1 }\end{array}$} & \multicolumn{2}{|c|}{$\% 95$ Güven aralığ 1} \\
\hline & & & & & & & & & En düşük & En yüksek \\
\hline \multirow[b]{2}{*}{$\begin{array}{l}\text { Satın alma } \\
\text { niyeti }\end{array}$} & Varyanslar eşit & 2,973 & 0,086 & 1,335 & 196 & 0,183 & 0,202 & \begin{tabular}{|l|}
0,151 \\
\end{tabular} & $-0,096$ & 0,500 \\
\hline & $\begin{array}{l}\text { Varyanslar eşit } \\
\text { değil }\end{array}$ & & & 1,335 & 192,985 & 0,183 & 0,202 & 0,151 & $-0,096$ & 0,500 \\
\hline \multirow[b]{2}{*}{$\begin{array}{l}\text { Duygusal } \\
\text { tepkiler }\end{array}$} & Varyanslar eşit & 0,332 & 0,565 & 0,122 & 195 & 0,903 & 0,016 & 0,132 & $-0,243$ & 0,275 \\
\hline & $\begin{array}{l}\text { Varyanslar eşit } \\
\text { değil }\end{array}$ & & & 0,122 & 194,454 & 0,903 & 0,016 & 0,132 & $-0,243$ & 0,275 \\
\hline \multirow{2}{*}{$\begin{array}{l}\text { Bilişsel } \\
\text { tepkiler }\end{array}$} & Varyanslar eşit & 0,529 & 0,468 & $-1,112$ & 195 & 0,268 & $-0,148$ & 0,133 & $-0,410$ & 0,114 \\
\hline & $\begin{array}{l}\text { Varyanslar eşit } \\
\text { değil }\end{array}$ & & & $-1,112$ & 194,565 & 0,267 & $-0,148$ & 0,133 & $-0,410$ & 0,114 \\
\hline
\end{tabular}


